\title{
A Study of Korean Literature Review Related to Speech Characteristics and Speech Therapy in Patients with Parkinson Disease
}

\author{
Ha Neul Kang ${ }^{1}$ (D) and Jae Yeon Yoo² (D) \\ 'Department of Otorhinolaryngology, Beautiful Voice Clinic, Seoul, Korea \\ ${ }^{2}$ Department of Speech-Language Pathology, Honam University, Gwangju, Korea \\ 파킨슨병 환자의 말 특성과 언어치료 관련 국내문헌연구 \\ 강하늘 ${ }^{1}$, 유재연 ${ }^{2}$ \\ 아름다운목소리 이비인후과, ${ }^{1}$ 호남대학교 언어치료학과2
}

The purpose of this study was to investigate the speech characteristics and speech therapy of Parkinson disease (PD). This study selected 28 papers published in Korea from 1998 to 2018 after searching the terms 'Parkinson voice' and 'Parkinson speech therapy.' Literature review had been conducted in the two aspects of speech characteristics and speech therapy. The speech characteristics were divided into respiration, phonation, articulation, prosody, vowel production, and voice questionnaire. Speech therapy was divided into Lee Sliverman voice treatment (LSVT) and other voice therapy. PD patients did not differ in respiration function compared to normal elderly people, but their speech and articulation function were poorer. There was also a difference in the speech rate, frequency of pause, and accuracy of vowel production compared with normal elderly people. PD had a lower VHI score and their voice related quality of life was a little poorer. The LSVT was typically used in speech therapy for PD. The methods of speech therapy for PD have been shown to improve respiration and phonation. It is necessary to establish voice norms in PD patients and develop effective speech therapy in the following study.

Keywords Parkinson disease; Voice quality; Speech therapy.

\section{서 론}

파킨슨병(Parkinson disease, PD)은 움직임을 개시하고 운동 계획을 유지시키는 뇌 기저핵의 손상으로 도파민 결핍이 나타나면서 발생하는 대표적인 중추신경계 퇴행성 운 동질환이다. 파킨슨병은 운동기능이 점차적으로 퇴행하여 근육경직, 진전, 운동 완서, 자 세 불완전 등의 증상을 보이며 말과 관련하여 호흡, 발성, 조음, 운율 등에 문제가 나타 나는 과소운동형 마비말장애(hypokinetic dysarthria)를 보인다.

주요 말 특성은 음질 이상(기식음성, 거친음성, 목쉰음성 등)과 단강도 및 단음도, 부 정확한 조음, 말 속도 변이, 말 뭉침(short rushes of speech), 비정상적인 운율 등이다. 또한 파킨슨병은 운동 이상뿐만 아니라 말의 문제로 인해 의사소통의 어려움을 가지며
Received November 5, 2018

Revised December 19, 2018

Accepted March 4, 2019

\section{Corresponding Author}

Jae Yeon Yoo, PhD

Department of Speech-Language

Pathology, Honam University,

100 Honamdae-gil, Gwangsan-gu,

Gwangju 62399, Korea

Tel +82-62-940-5546

Fax +82-62-940-5196

E-mail slpyoo@hanmail.net

\section{ORCID iDs}

Ha Neul Kang (D)

https://orcid.org/0000-0003-0133-2894

Jae Yeon Yoo (D)

https://orcid.org/0000-0001-5575-1280

\footnotetext{
This is an Open Access article distributed under the terms of the Creative Commons Attribution Non-Commercial License (https://creativecommons.org/ licenses/by-nc/4.0) which permits unrestricted non-commercial use, distribution, and reproduction in any medium, provided the original work is properly cited.
} 
삶의 질에도 영향을 미친다.

이와 같은 파킨슨병 환자들의 말 명료도를 증가시키기 위 한 다양한 중재 전략들이 연구되어 왔다. 파킨슨병으로 인한 마비말장애의 전통적인 언어치료는 전형적으로 조음, 속도, 운율에 초점을 두고 일주일에 1 2회 정도 실시한다. 그러나 이러한 치료 방법은 거의 효과가 없었다. 한편, 상대적으로 힘 을 주어 발성하는 단순한 과제를 거의 매일 실시하는 집중적 인 음성치료는 파킨슨병을 가진 마비말장애 환자의 발화에 도움이 된다는 것이 밝혀졌다. ${ }^{1-3)}$ 그리고 Lee Silverman voice treatment(LSVT) 프로그램은 파킨슨병 환자들의 음 강 증진으로 인해 의사소통을 개선시키는 데 효과적인 치료 방법으로 사용되고 있다.")

본 연구는 파킨슨병 환자의 말 특성 및 언어치료 중심으로 국내 문헌을 고찰하여 연구 결과들의 경향성을 알아봄으로 써 파킨슨병 환자의 의사소통 능력 관리를 위한 후속 연구의 필요성을 제시하고자 하였다.

\section{본 론}

본 연구는 검색사이트 RISS, KISS, DBpia 등에서 '파킨슨 음 성', '파킨슨 언어치료, '파킨슨 말 특성' 등의 검색어를 사용하여 1998 2018년까지 국내에서 출판된 파킨슨병 말 특성 및 언어 치료 연구 논문 28편을 선정하여 분석하였다(Appendix).

\section{말 특성}

\section{호 흡}

파킨슨병 환자의 호흡기능을 알아본 연구결과는 다음과 같 았다. 호흡기능 중 노력성 폐활량(forced vital capacity, FVC), 1 초간 노력성 호기량(1 second forced expiratory volume, $\mathrm{FEV}_{1}$ ), 노력성 폐활량에 대한 1초간 노력성 호기량의 비 $\left(\mathrm{FEV}_{1} / \mathrm{FVC}\right)$, 평균호기류율(mean flow rate) 등에서 파킨슨병 집단과 정상노인 집단 간에 호흡 기능에 유의한 차이가 없는 것으로 나타났다. ${ }^{5-7)}$ 반면, 성문하압(subgolttal pressure, $\mathrm{P}_{\mathrm{sub}}$ )은 집단 간에 차이가 없었다.,7)와 파킨슨병 집단이 유의하게 낮다 는 연구가 있었다.)

최대발성지속시간(maximum phonation time, MPT)은 파킨슨병 집단이 정상노인 집단보다 유의하게 짧았다는 결 과5,8)와 두 집단 간에 차이가 없다는 결과도 있었다.6,79)

파킨슨병 환자의 호흡 기능은 전반적으로 정상노인과 차 이가 없었으나 파킨슨병의 유형과 중증도에 따라 $\mathrm{MPT}, \mathrm{P}_{\mathrm{sub}}$ 등에서 차이가 있는 것으로 나타났다.

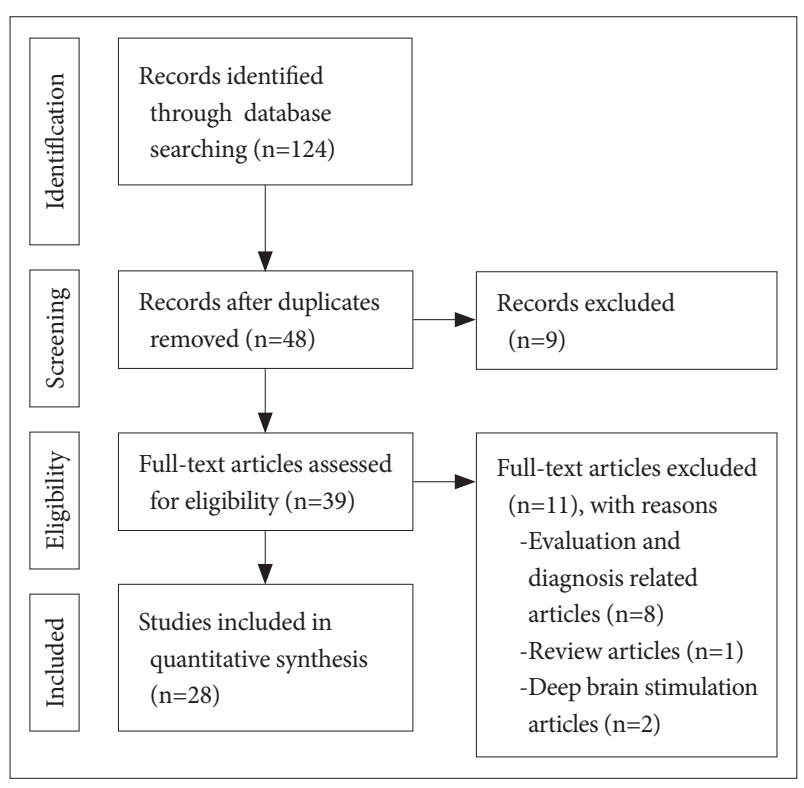

Fig. 1. Flow chart of study selection in the meta-analysis.

\section{발 성}

파킨슨병 환자의 음도는 정상노인에 비해 남성의 경우 음 도가 높은 반면, 여성의 경우 음도가 낮은 경향이 있었다. 남 성의 집단에서는 파킨슨병의 중증도가 심할수록 음도가 더 낮은 것으로 나타났다. ${ }^{8)}$ 또한 파킨슨병 환자의 음도 범위는 유의하게 더 좁은 것으로 나타났다. ${ }^{9}$

파킨슨병 환자는 정상노인에 비해 음질이 유의하게 더 좋 지 않다는 연구5,9,10와 유의하지는 않지만 약간 음질이 좋지 않다는 연구가 있었다. ${ }^{899}$ 이러한 결과는 파킨슨병 환자가 정 상노인에 비해 음질이 더 좋지 않다는 것을 의미하였다.

\section{조음운동}

파킨슨병 환자를 대상으로 교호운동(diadochokinesis, $\mathrm{DDK}$ 과제를 통해 조음운동능력을 살펴보았다. 파킨슨병 환 자는 전반적으로 $\mathrm{DDK}$ 속도가 느리고 규칙성은 떨어지는 것 으로 나타났다.9,12) 또한 발화 과제 유형인 교대운동속도(alternating motion rate, AMR), 일련운동속도(sequential motion rate, SMR)에 따라 속도와 규칙성이 상이하게 나타났다. ${ }^{11}$ 이는 파킨슨병 환자의 운동능력이 조음기관의 움직임에 영향 을 미쳐 속도가 느려지고 발화하는 동안 스스로 시간을 조절 하는 능력이 손상되어 불규칙적으로 나타난 것으로 보인다. ${ }^{2)}$ 또한 파킨슨병의 중증도에 따라 속도의 차이는 없었으나 ${ }^{11,13)}$ 과제에 따라 규칙성에 차이가 있었다.11)

\section{초분절적 특성}

파킨슨병 환자의 조음 속도는 정상노인과 차이가 없다 ${ }^{14}$ 와 
정상노인보다 조음속도가 더 빠르다도로 나타났고, 전체 말 속도는 두 집단 간에 차이가 없었다.14,15) 한편, 파킨슨병 환자 의 조음 비율은 정상노인보다 유의하게 높게 나타났다. ${ }^{14)}$

발화 시 심은 파킨슨병 환자가 정상노인에 비해 더 짧고 심 빈도와 쉼 비율이 더 낮은 경향이 있는 것으로 나타났다. ${ }^{15)}$

파킨슨병 환자는 발화 시 비유창성(정상적인 비유창성, 병 리적인 비유창성) 구간의 시간 길이에서 정상노인과 유의한 차이는 없었다. ${ }^{14,15}$

파킨슨병 환자의 조음 속도는 환자들마다 차이가 있었고 전반적으로 쉼의 길이는 더 짧고 횟수는 적었다. 문장이 길어 질수록 파킨슨병 환자는 정상노인보다 말 속도가 빠른 것으 로 나타났는데 이는 강직된 운동능력으로 인해 미리 조음동 작이 끝나버리는 현상과 말 분절(자모음) 지속 시간 감소의 결과로 보인다. ${ }^{15}$

\section{모음 산출}

파킨슨병 환자의 모음 정확도를 알아보기 위해 모음 공간 을 분석한 결과, 파킨슨병 환자 집단이 정상노인 집단보다 모 음 면적이 더 좁은 것으로 나타났다. ${ }^{16-19)}$ 이는 파킨슨병 환자 의 혀 운동 범위가 정상노인에 비해 상대적으로 좁은 것과 관련이 있다.

\section{음성 설문}

파킨슨병 환자를 대상으로 한 음성 설문 연구 결과, 음성 장애지수(Voice Handicap Index, VHI), 음성과 관련된 삶 의 질(Korean voice-related quality of life, K-VRQOL), 그 리고 말장애지수(Speech Handicap Index) 등에서 음성장 애의 정도가 심하고 음성과 관련된 삶의 질이 대체적으로 낮 게 나타났다.20,21) 반면, 또 다른 연구에서는 파킨슨병 환자가 $\mathrm{VHI}$ 점수에서 높은 경향을 보이나 두 집단 간 차이가 없는 것으로 나타났다. ${ }^{\text {) }}$

파킨슨병 환자는 파킨슨병의 중증도가 높을수록 자신의 음성 문제에 대해 민감하며 말 명료도가 낮고 우울증세가 심할수록 말 문제를 심각하게 여기는 것으로 보인다.

\section{파킨슨병 환자의 언어치료}

\section{LSVT}

파킨슨병 환자를 대상으로 LSVT를 시행한 결과, 음향학 적 측면에서 발성과 ${ }^{22-24)}$ 음질이 개선되었고, ${ }^{22-25)}$ 공기역학적 측면에서는 MPT가 향상되었다. ${ }^{22,26)}$ 말 명료도는 치료 후 유 의하게 개선되었고 ${ }^{23}$ 유의한 수준은 아니지만 어느 정도 말 명료도가 향상되었다는 연구 결과도 있었다.23)
LSVT는 파킨슨병 환자의 성대 내전력을 향상시키고 호흡 량을 증가시켜 음도 및 강도, 음질, 말 명료도, 호흡능력 등 을 개선시키는 데 유용하며, 파킨슨병의 중증도나 치료 기간 등에 따라 음질 개선의 차이는 다르게 나타났다.

기 타

음성조절훈련

음성조절훈련은 음도와 강도를 변화시켜 발화하는 훈련이다. 음성조절훈련 결과, 음질과 음성떨림의 개선이 나타났다. 또한 음도와 강도의 제시 조건에 따라 단어 및 문장 명료도에서 다 소 차이가 있는 것으로 나타났다.26,27) 이는 음성조절훈련이 대 상자의 음질을 개선시키는 동시에 발화의 기능을 향상시킴으 로써 전반적인 발화 명료도가 향상된 것으로 볼 수 있다.7)

음악활동을 통한 음성치료

악센트 기법을 응용한 치료 프로그램을 적용한 결과, 파킨 슨병 환자의 MPT와 주파수 범위 및 강도 범위, 음질이 유의 하게 개선되었다. ${ }^{28)}$

노래창작활동을 포함한 치료 프로그램을 적용한 결과, 파 킨슨병 환자의 VHI와 노인우울 척도(Geriatric Depression Scale) 점수가 감소되었고, $\mathrm{K}-\mathrm{VRQOL}$ 점수가 향상되었으며 호흡패턴 유지, 발성 시간 증가, 운율 변화 등으로 음성의 질 이 향상된 것으로 나타났다. ${ }^{29}$

합창중재 프로그램은 호흡 길이, 음도, 음질 개선과 함께 $\mathrm{VHI}, \mathrm{K}-\mathrm{VRQOL}$ 에서도 긍정적인 영향을 미친 것으로 보고 되었다. ${ }^{30)}$

\section{주파수 변조 프로그램}

특발성 파킨슨병 환자를 대상으로 주파수 변조 프로그램 을 적용한 결과, 주파수 범위 및 강도 범위가 증가하고 단음 도, 단강도, 음질 등의 개선을 보였다. 또한 이 프로그램은 불 명료한 발화의 원인 중 하나인 기식음성의 개선에 특히 효과 적인 것으로 나타났다. ${ }^{31}$

\section{클리어 스피치}

또박또박 조금 크게 말하도록 하는 클리어 스피치(clear speech)를 파킨슨병 환자에게 적용한 결과, 발화 기본 주파 수, 음도 범위, 말 속도에서 유의한 차이가 나타났고 음성강 도와 평균 발성 기류에서는 유의한 차이가 나타나지 않은 것 으로 보고되었다. ${ }^{32)}$ 파킨슨병 환자는 클리어 스피치를 통해 호흡보다는 음향학적 및 초분절적인 측면에서 음성 개선이 나타났다. 


\section{결 론}

파킨슨병 환자는 정상노인과 비교했을 때, 호흡기능은 차 이가 없었으나 $\mathrm{MPT}, \mathrm{P}_{\mathrm{sub}}$ 과 음도 및 음질 파라미터에서 유의 한 차이가 있었고 전반적으로 음성에 문제를 보였다. 또한 정 상노인보다 모음 공간 면적이 좁았고 조음운동의 속도는 감 소하고 불규칙적이었다. 말 속도는 빨라지는 편이었으며 심은 더 짧아지고 횟수도 적게 나타났다. 이는 $\mathrm{PD}$ 의 폐근육 및 후 두 강직, 근긴장 이상 등의 신체적 운동 조절의 문제와 관련 이 있다.

파킨슨병 환자는 대체적으로 자신이 음성문제가 있다고 보고하였고 음성과 관련된 삶의 질도 다소 낮은 것으로 나타 났다.

이와 같은 파킨슨병의 말의 특성은 파킨슨병의 유형, 환자 연령, 약물 복용, 발병 기간, 중증도 등에 영향을 받을 수 있다. 파킨슨병 환자를 대상으로 한 치료는 주로 LSVT를 사용 하였고 이외에도 음성조절훈련, 음악활동을 통한 음성치료, 주파수 변조 프로그램, 클리어 스피치 등을 이용하였다. 이러 한 치료를 통해 파킨슨병 환자의 단음도 및 단강도, 말 명료 도, 음질 등이 향상됨으로써 삶의 질에도 긍정적인 영향을 주는 것으로 나타났다.

차후 연구로는 파킨슨병 환자를 대상으로 한 음성 규준 데이터 확립 연구와 연구 결과가 상반되게 나타난 연구 주제 에 대한 연구, 그리고 파킨슨병 환자의 음성 개선을 위한 다 양한 치료 효과 연구가 필요할 것이다.

중심 단어: 파킨슨병, 음성특성, 언어치료.

\section{Acknowledgments}

None.

Conflicts of Interest.

The authors have no financial conflicts of interest.

\section{Authors' Contribution}

Conceptualization: Ha Neul Kang. Data curation: Jae Yeon Yoo. Formal analysis: Ha Neul Kang. Investigation: Jae Yeon Yoo. Methodology: Jae Yeon Yoo. Resources: Ha Neul Kang. Software: Ha Neul Kang. Validation: Ha Neul Kang. Writing-original draft: Ha Neul Kang. Writing - review \& editing: Jae Yeon Yoo. Approval of final manuscript: all authors.

\section{REFERENCES}

1. Johnson JA, Pring TR. Speech therapy and Parkinson's disease: a review and further data. Br J Disord Commun 1990;25(2):183-94.

2. Robertson SJ, Thomson F. Speech therapy in Parkinson's disease: a study of the efficacy ad long term effects of intensive treatment. Br J Disord Commun 1984;19(3):213-24.

3. Scott S, Caird FI. Speech therapy for Parkinson's disease. J Neurol Neurosurg Psychiatry 1983;46(2):140-4.

4. Kim YK. Treatment efficacy of LSVT program on individuals with
Parkinson disease : a meta analysis [dissertation]. Seoul: Myongji University;2012.

5. Chun EA, Shon YH, Baek SJ, Lee PH, Nam CM, Lee JE, et al. Characteristics of respiration and phonation in patients with young-onset Parkinson's disease compared to normal adults. Commun Sci Disord 2010;15(4):537-48.

6. Cho SA, Sohn YH, Baek SJ, Lee PH, Lee JE, Choi Yl. Respiratory functions and characteristics of phonation in patients with de novo idiopathic Parkinson's diseases. Phonetics and Speech Science 2010;2(4):75-82.

7. Kim BM, Sohn YH, Baek SJ, Lee PH, Nam CM, Lee JE, et al. Characteristics of speech breathing in de novo idiopathic Parkinson's disease during passage reading tasks. Phonetics and Speech Sciences 2011;3(1):103-10.

8. Lee JY. Acoustic analysis of speech in patients with idiopathic Parkinson's disease [dissertation]. Daejeon: Chungnam National University;2007.

9. Kang YA, Kim YD, Ban JC, Seong CJ. A comparison of the voice differences of patients with idiopathic Parkinson's disease and a normal-aging group. Phonetics and Speech Sciences 2009;1(1):99107.

10. Lee IA, Kim MJ, Hwang YJ. A comparison of the voice difference of persons with idiopathic Parkinson's disease and a normal group in five vowels. Phonetics and Speech Sciences 2012;4(1):119-24.

11. Jung EY, Cho SR, Kim YJ, Kim HH. Characteristics of diadochokinesis in hypokinetic dysarthria: rate and regularity. Commun Sci Dis 2011;16(1):74-82.

12. Kang YA, Park HY, Koo BS. An acoustic analysis of diadochokinesis in patients with Parkinson's disease. Phonetics and Speech Sciences 2013;5(4):3-15.

13. Kim SW, Yoon JH, Lee SJ. Acoustic characteristics of 'short rushes of speech' using alternate motion rates in patients with Parkinson's disease. Phonetics and Speech Sciences 2015;7(2):55-62.

14. Ko YM, Kim DY, Choi Yl, Kim HH. Speech rate and pause characteristics in patients with Parkinson's disease. Phonetics and Speech Sciences 2010;2(4):173-84.

15. Kim SW. A study of speaking rate on Parkinson's disease with palilalia. Phonetics and Speech Sciences 2016;8(3):61-6.

16. Kang YA, Yoon KC, Lee HS, Seong CJ. A comparison of parameters of acoustic vowel space in patients with Parkinson's disease. Phonetics and Speech Sciences 2010;2(4):185-92.

17. Shim HJ, Park WK, Ko DH. Characteristics of speech intelligibility and the vowel space in patients with Parkinson's disease. Phonetics and Speech Sciences 2012;4(3):161-9.

18. Lee IA, Hwang YJ. A study of vowel articulatory space and speechformant in patients with idiopathic Parkinson's disease according to sex. Journal of Special Education \& Rehabilitation Science 2011;50(4); 203-20.

19. Lee HJ. F2 slopes of Korean diphthongs: comparison between Parkinson's disease groups and normal groups [dissertation]. Seoul: Yonsei University;2012.

20. Yu G, Jang IS, Kim LH. Voice handicap index and voice-related quality of Life in idiopathic Parkinson's disease. Journal of Oriental Neuropsychiatry 2013;24(2):155-62.

21. Mun HJ, Cho SR, Cho SH, Kim HH. Application of the speech handicap index on patients with Parkinson's disease. Commun Sci Disord 2018;23(1):160-8.

22. Chu IS, Kang SK. The effect of voice treatment on patients with idiopathic Parkinson disease. Journal of Speech \& Hearing Disorders 1998;7(1):113-28.

23. Kim WA. Effect of Lee Silverman voice treatment (LSVT) on speech intelligibility of spontaneous speech in patients with idiopathic Parkinson's disease [dissertation]. Seoul: Ewha Womans University;2004. 24. Kang YA. Effects of the Lee Silverman voice treatment (LSVT) on 
voice quality of patients with Parkinson's disease [dissertation]. Daejeon: Chungnam National University;2007.

25. Choi SH. The effect of Lee Silverman voice treatment $\left(\mathrm{LSVT}^{\circledR}\right)$ on Parkinsonian phonation: nonlinear dynamic, perturbation, and perceptual analysis. Commun Sci Dis 2011;16(3):335-45.

26. Lee OB, Jeong OR, Ko DH. The effects of voice and speech intelligibility improvements in Parkinson disease by training loudness and pitch: a case study. Speech Sciences 2001;8(3):173-84.

27. Lee OB, Jeong OR. The effects of voice control training on voice and speech of individuals with Parkinson disease. Journal of Speech \& Hearing Disorders 2005;14(2):155-66.

28. Heo SM. The effects of Korean traditional rhythm therapy program on voice in Parkinson's disease [dissertation]. Gyeongsan: Daegu University;2005.
29. Han EY. Use of the structured singing activities to improve of the vocal quality and alleviate of the depression symptoms for clients with Parkinson's disease: case studies [dissertation]. Seoul: Ewha Womans University;2015.

30. Chung YM. Effects of choral singing on improvement of vocal function and satisfaction among patients with Parkinson's diseases. Seoul: Ewha Womans University;2017.

31. Jeong NG. The effects of frequency altered program on voice improvements in patients with Parkinson's disease [dissertation]. Gyeongsan: Daegu University;2005.

32. Shin HB, Ko DH. An aerodynamic and acoustic characteristics of clear speech in patients with Parkinson's disease. Phonetics and Speech Sciences 2017;9(3):67-74. 


\section{Appendix}

\section{국내 연구 개관(Domestic Research Overview)}

\section{1. 파킨슨병 환자의 말 특성}

\begin{tabular}{|c|c|c|c|c|}
\hline 연 도 & 제 목 & 저 자 & 연구 대상 & 연구 주제 \\
\hline 2010 & $\begin{array}{l}\text { 조기발병형 파키슨병 } \\
\text { 환자와 정상인의 호흡 및 } \\
\text { 발성 특성 비교 }\end{array}$ & $\begin{array}{l}\text { 전은애, 손영호, } \\
\text { 백승재, 이필휴, } \\
\text { 남정모, 이지은, } \\
\text { 최예린 }\end{array}$ & $\begin{array}{l}\text { 조기발병형 } \\
\text { 파킨슨병 환자 6명, } \\
\text { 정상성인 6명 }\end{array}$ & $\begin{array}{l}\text { 파킨슨병의 음성 특성을 확인하기 위해 } \\
\mathrm{YOPD} \text { 를 대상으로 음성문제가 호흡기능 혹은 } \\
\text { 발성 능력에서 기인한 것인지 알아보고자 함 }\end{array}$ \\
\hline 2010 & $\begin{array}{l}\text { De novo 특발성 파킨슨병 } \\
\text { 환자의 호흡 및 발성 특성 }\end{array}$ & $\begin{array}{l}\text { 조선아, 손영호, } \\
\text { 백승재, 이필휴, } \\
\text { 이지은, 최예린 }\end{array}$ & $\begin{array}{l}\text { 특발성 파킨슨병 } \\
\text { 환자 20명, } \\
\text { 정상노인 20명 }\end{array}$ & $\begin{array}{l}\text { 치료받은 경험이 없는 파킨슨병 환자의 } \\
\text { 호흡 및 발성 특성을 살펴보고자 함 }\end{array}$ \\
\hline 2011 & $\begin{array}{l}\text { De novo 특발성 파킨슨병 } \\
\text { 환자의 문단 읽기 과제에서의 } \\
\text { 호흡 특성 }\end{array}$ & $\begin{array}{l}\text { 김병미, 손영호, } \\
\text { 백승재, 이필휴, } \\
\text { 남정모, 이지은, } \\
\text { 최예린 }\end{array}$ & $\begin{array}{l}\text { 특발성 파킨슨병 } \\
\text { 환자 20명, } \\
\text { 정상성인 20명 }\end{array}$ & $\begin{array}{l}\text { 특발성 파킨슨병 환자와 정상인을 대상으로 } \\
\text { 읽기 시 호흡 특성을 비교하고 } 1 \text { 회 호흡당 } \\
\text { 음절수의 차이에 영향을 미치는 요인을 } \\
\text { 살펴보고자 함 }\end{array}$ \\
\hline 2007 & $\begin{array}{l}\text { 파킨슨병 환자 언어의 } \\
\text { 음성학적 분석 }\end{array}$ & 이준영 & $\begin{array}{l}\text { 파킨슨병 환자 50명, } \\
\text { 정상노인 } 21 \text { 명 }\end{array}$ & $\begin{array}{l}\text { 파킨슨병 환자 언어의 음성학적 특징을 } \\
\text { 분석하여 음성학적 변화와 파킨슨병의 } \\
\text { 임상 증상 또는 진행 정도와 관련성을 } \\
\text { 알아봄으로써 언어변화가 질환의 상태에 } \\
\text { 대한 지표가 될 수 있는 알아보고자 함 }\end{array}$ \\
\hline 2009 & $\begin{array}{l}\text { 파킨슨병 환자와 정상 노인의 } \\
\text { 음성비교 }\end{array}$ & $\begin{array}{l}\text { 강영애, 김용덕, } \\
\text { 반재천, 성철재 }\end{array}$ & $\begin{array}{l}\text { 특발성 파킨슨병 } \\
\text { 환자 } 15 \text { 명, } \\
\text { 정상노인 } 15 \text { 명 }\end{array}$ & $\begin{array}{l}\text { 파킨슨병의 초진 환자와 정상노인의 음성을 } \\
\text { 비교하여 병의 유무로 인해 음성에 어떤 } \\
\text { 변화가 초래되는지 음향음성학적 관점에서 } \\
\text { 확인하고자 함 }\end{array}$ \\
\hline 2012 & $\begin{array}{l}\text { 파킨슨병 환자와 정상노인의 } \\
\text { 모음 산출 특성 비교 }\end{array}$ & $\begin{array}{l}\text { 이인애, 김문정, } \\
\text { 황영진 }\end{array}$ & $\begin{array}{l}\text { 특발성 파킨슨병 } \\
\text { 환자 8명, } \\
\text { 정상노인 } 24 \text { 명 }\end{array}$ & $\begin{array}{l}\text { 파킨슨병 환자와 정상노인의 음성을 } \\
5 \text { 가지 모음으로 비교하고, 각 집단별로 } 5 \text { 가지 } \\
\text { 모음 간의 상관정도를 비교함으로써 병의 } \\
\text { 유무에 따른 음향학적 특징을 살펴보고자 함 }\end{array}$ \\
\hline 2011 & $\begin{array}{l}\text { 운동감소형 마비말장애의 } \\
\text { 조음교대운동 특성: } \\
\text { 속도 및 규칙성 }\end{array}$ & $\begin{array}{l}\text { 정은영, 조성래, } \\
\text { 김윤정, 김향희 }\end{array}$ & $\begin{array}{l}\text { 파킨슨병 환자 18명, } \\
\text { 정상노인 26명 }\end{array}$ & $\begin{array}{l}\text { 운동감소형 마비말장애군과 정상군 간 } \\
\text { 또는 운동감소형 마비말장애군의 중증도에 } \\
\text { 따라 조음교대운동 속도 및 규칙성에 } \\
\text { 차이가 있는지를 살펴보고자 함 }\end{array}$ \\
\hline 2013 & $\begin{array}{l}\text { 파킨슨병 환자 대상 } \\
\text { 조음교대운동의 음향적 분석 }\end{array}$ & $\begin{array}{l}\text { 강영애, 박현영, } \\
\text { 구본석 }\end{array}$ & $\begin{array}{l}\text { 특발성 파킨슨병 47명, } \\
\text { 정상노인 20명 }\end{array}$ & $\begin{array}{l}\text { 개발된 DDK 프로그램을 이용하여 파킨슨병 } \\
\text { 환자 대상으로 조음교대운동 속도에 대한 } \\
\text { 음향학적 정보를 제공하고자 함 }\end{array}$ \\
\hline 2015 & $\begin{array}{l}\text { 파킨슨병 환자의 교대운동속도 } \\
\text { 과제에서 관찰된 '말 뭉침'의 } \\
\text { 음향학적 특성 }\end{array}$ & $\begin{array}{l}\text { 김선우, 윤지혜, } \\
\text { 이승진 }\end{array}$ & 파킨슨병 환자 9명 & $\begin{array}{l}\text { AMRs 과제를 이용하여 청지각적으로만 } \\
\text { 설명되어 온 } \mathrm{PD} \text { 환자의 말 뭉침을 음향학적 } \\
\text { 분석에 기초하여 특성을 확인하고자 함 }\end{array}$ \\
\hline 2010 & $\begin{array}{l}\text { 파킨슨병 환자의 말 속도와 } \\
\text { 심 특성 }\end{array}$ & $\begin{array}{l}\text { 고열매, 김덕용, } \\
\text { 최예린, 김향희 }\end{array}$ & $\begin{array}{l}\text { 특발성 파킨슨병 } \\
\text { 환자 } 7 \text { 명, } \\
\text { 정상 성인 13명 }\end{array}$ & $\begin{array}{l}\text { 파킨슨병 환자의 말 속도 특성과 말 속도에 } \\
\text { 영향을 미치는 쉼 특성에 대해 알아보고자 함 }\end{array}$ \\
\hline
\end{tabular}




\begin{tabular}{|c|c|c|c|c|}
\hline 연 도 & 제 목 & 저 자 & 연구 대상 & 연구 주제 \\
\hline 2016 & $\begin{array}{l}\text { 동어반복증을 동반한 } \\
\text { 파킨슨병 환자의 말속도 연구 }\end{array}$ & 김선우 & $\begin{array}{l}\text { 특발성 파킨슨병 } \\
\text { 환자 5명, } \\
\text { 정상 성인 8명 }\end{array}$ & $\begin{array}{l}\mathrm{PDP} \text { 를 대상으로 습관적인 말 빠르기를 반영한 } \\
\text { 전체 말 속도와 조음 기관의 실제적인 움직임을 } \\
\text { 반영한 조음 속도를 음향분석기기를 활용하여 } \\
\text { 살펴보고자 함 }\end{array}$ \\
\hline 2010 & $\begin{array}{l}\text { 파킨슨병 환자의 음향 모음 } \\
\text { 공간 파라미터 비교 }\end{array}$ & $\begin{array}{l}\text { 강영애, 윤규철, } \\
\text { 이학승, 성철재 }\end{array}$ & $\begin{array}{l}\text { 특발성 파킨슨병 32명, } \\
\text { 정상노인 20명 }\end{array}$ & $\begin{array}{l}\text { 파킨슨병 음향 모음 공간 파라미터를 국내 } \\
\text { 환자를 대상으로 적용하여 어떤 특징을 있는지 } \\
\text { 알아보고 새롭게 제시하는 모음 오각형 } \\
\text { 파라미터의 유용성 여부를 확인하고자 함 }\end{array}$ \\
\hline 2012 & $\begin{array}{l}\text { 파킨슨병 환자의 말 명료도와 } \\
\text { 모음 공간 특성 }\end{array}$ & $\begin{array}{l}\text { 심희정, 박원경, } \\
\text { 고도흥 }\end{array}$ & $\begin{array}{l}\text { 파킨슨병 } \\
\text { 환자 20명, } \\
\text { 정상노인 10명 }\end{array}$ & $\begin{array}{l}\text { 파킨슨병 환자들을 대상으로 집단 및 성별로 } \\
\text { 구분하여 개관적 수치를 비교 분석하고 } \\
\text { 말 명료와 모음 공간의 특성을 살펴보고자 함 }\end{array}$ \\
\hline 2011 & $\begin{array}{l}\text { 성별에 따른 파킨슨병 환자의 } \\
\text { 모음 공간 발화 포먼트 연구 }\end{array}$ & 이인애, 황영진 & $\begin{array}{l}\text { 파킨슨병 } \\
\text { 환자 8명, } \\
\text { 정상노인 24명 }\end{array}$ & $\begin{array}{l}\text { 파킨슨병 환자와 정상노인의 모음 공간과 } \\
\text { 발화포먼트를 이용하여 각각 성별로 구별하여 } \\
\text { 차이를 알아보고자 함 }\end{array}$ \\
\hline 2012 & $\begin{array}{l}\text { 이중모음에서의 제2포먼트 } \\
\text { 기울기(F2 slope): 파킨슨병 } \\
\text { 환자군과 정상군 간의 비교 }\end{array}$ & 이혜진 & $\begin{array}{l}\text { 파킨슨병 여성 } \\
\text { 환자 9명, } \\
\text { 정상 여성 성인 10명 }\end{array}$ & $\begin{array}{l}\text { 이중모음이 들어간 단어에서 파킨슨병 } \\
\text { 환자군과 정상군의 F2 slope에 차이가 } \\
\text { 있는지 알아보고자 함 }\end{array}$ \\
\hline 2013 & $\begin{array}{l}\text { 파킨슨병 환자의 } \\
\text { 음성장애지수 및 음성관련 } \\
\text { 삶의 질 연구 }\end{array}$ & $\begin{array}{l}\text { 유경, 장인수, } \\
\text { 김락형 }\end{array}$ & $\begin{array}{l}\text { 파킨슨병 } \\
\text { 환자 } 17 \text { 명 }\end{array}$ & $\begin{array}{l}\text { 음성장애지수 및 음성 관련 삶의 질을 통해 } \\
\text { 파킨슨병 환자에서 음성장애로 인한 어려움 } \\
\text { 및 삶의 미치는 영향을 살펴보고자 함 }\end{array}$ \\
\hline 2018 & $\begin{array}{l}\text { 파킨슨병 환자에 대한 } \\
\text { 말장애지수 적용 }\end{array}$ & $\begin{array}{l}\text { 문효진, 조성래, } \\
\text { 최성희, 김향희 }\end{array}$ & $\begin{array}{l}\text { 파킨슨병 } \\
\text { 환자 48명 }\end{array}$ & $\begin{array}{l}\text { 파킨슨병 환자에게 } \mathrm{SHI} \text { 를 적용하여 말장애 } \\
\text { 인식을 파악하고, } \mathrm{SHI} \text { 점수와 상관관계가 } \\
\text { 있는 요인들에 대해 그 영향력을 확인하고자 함 }\end{array}$ \\
\hline
\end{tabular}

\section{2. 파킨슨병 환자의 언어치료}

\begin{tabular}{|c|c|c|c|c|}
\hline 연 도 & 제 목 & 저 자 & 연구 대상 & 연구 주제 \\
\hline 1998 & $\begin{array}{l}\text { 특발성 파킨슨병 환자들에 } \\
\text { 대한 음성치료 효과 }\end{array}$ & 추인숙, 강수균 & $\begin{array}{l}\text { 특발성 파킨슨병 } \\
\text { 환자 2명 }\end{array}$ & $\begin{array}{l}\text { LSVT 수정 프로그램을 한국의 특발성 } \\
\text { 파킨슨병 환자들에게 적용했을 때 음성치료의 } \\
\text { 개선에 효과가 있는지 밝히고자 함 }\end{array}$ \\
\hline 1997 & $\begin{array}{l}\text { LSVT프로그램이 특발성 } \\
\text { 파킨슨병 환자의 자발화 } \\
\text { 말 명료도에 미치는 효과 }\end{array}$ & 김우아 & $\begin{array}{l}\text { 특발성 파킨슨병 } \\
\text { 환자 } 11 \text { 명 }\end{array}$ & $\begin{array}{l}\text { LSVT의 치료 효과를 직접적인 자발화 말 명료도 } \\
\text { 평가로 확인하고, 자발화 말 명료도의 향상을 } \\
\text { 예측할 수 있는 변인을 밝히고자 함 }\end{array}$ \\
\hline 2007 & $\begin{array}{l}\text { LSVT에 의한 파킨슨병 } \\
\text { 환자의 음성장애치료에 } \\
\text { 관한 연구 }\end{array}$ & 강영애 & $\begin{array}{l}\text { 특발성 파킨슨병 } \\
\text { 환자 2명, } \\
\text { 혈관성 파킨슨 } \\
\text { 증후군 환자 } 1 \text { 명 }\end{array}$ & $\begin{array}{l}\text { 수정 LSVT 프로그램의 중재가 파킨슨병 } \\
\text { 환자의 음성을 개선의 효과를 음향적으로 } \\
\text { 확인하고 개선의 정도를 알아보고자 함 }\end{array}$ \\
\hline 2011 & $\begin{array}{l}\text { 파킨슨씨병 음성에 대한 } \\
\text { 리실버만 음성치료의 효과: } \\
\text { 비선형의 역동적, 섭동적, } \\
\text { 청지각적 분석 }\end{array}$ & 최성희 & $\begin{array}{l}\text { 특발성 파킨슨병 } \\
\text { 환자 8명(실험집단), } \\
\text { 특발성 파키슨병 } \\
\text { 환자 7명(대조집단) }\end{array}$ & $\begin{array}{l}\text { 파킨슨씨병 환자의 음성에 대한 1단계 수준의 } \\
\text { 치료 효과를 조사하고, 비선형 역동적 음향학적 } \\
\text { 접근법이 파킨슨씨병에서 흔히 관찰되는 } \\
\text { 비주기적인 음성을 정량화할 수 있는지 } \\
\text { 평가하고자 함 }\end{array}$ \\
\hline
\end{tabular}




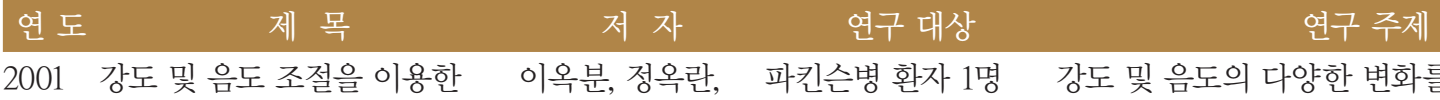

2001 강도 및 음도 조절을 이용한 훈련이 파킨슨병 환자의

음성 및 발화 명료도 개선에 미치는 효과

2005 파킨슨증 화자의 음성 및 발화 개선을 위한 음성조절

훈련 효과-훈련 방법의 효과 비교-

2004 장단을 이용한 치료 프로그램이 허수민 파킨슨병 환자의 음성 개선에 미치는 효과

2015 구조화된 노래활동을 통한 파킨슨병 내담자의 음성의 질 향상과 우울 감소에 관한 사례

2017 합창 중재 프로그램이 파킨슨병 환자의 음성 개선 및 음성 만족도에 미치는 영향

2005 주파수 변조 프로그램이 파킨슨병 환자의 음성 개선에 미치는 효과

2017 파킨슨 환자의 클리어 스피치 전후 음향학적 공기역학적 특성 고도흥

한은영 정유미 정년기

\section{이옥분, 정옥란 파킨슨증 환자 3 명}

강도 및 음도의 다양한 변화를 이용한 훈련이 파킨슨병 환자의 구어 명료도에 개선에 미치는 영향을 알아보고자 함

파킨슨증 화자들을 대상으로 음성 조절 훈련 방법에 따라 음성 및 발화 개선에 미치는 영향을 알아보고자 함

특발성 파킨슨병 3명(실험집단), 장단을 이용한 치료 프로그램을 실시한 실험집 특발성 파킨슨병 3명 (대조집단) 단과 치료를 실시하지 않은 통제집단으로 나누어 확인하고자 함 파킨슨병 환자 3 명 음성 개선의 효과에 유의한 차이가 있는지를 파킨슨병 환자에게 노래 중재를 적용한 구조화된 노래활동 프로그램을 실시하여 음성의 질 향상과 우울 감소에 대한 변화를 알아보고자 함

파킨슨병 환자 6명 (실험집단), 파킨슨병 환자 5 명 어떠한 영향을 미치는지 알아보고자 함 (대조집단)

특발성 파킨슨병 주파수 변조 프로그램이 파킨슨병 환자의 환자 여성 3 명 음성 개선에 미치는 효과를 알아보고자 함 신희백, 고도흥 파킨슨병 환자 10 명

클리어 스피치가 중재 기법으로 어느 정도의 효율성을 가지고 있는지를 확인하여 최적화된 클리어 스피치 훈련 프로그램을 개발하기 위한 근거 자료로 사용하고자 함 